\title{
Black Bengal goat keeping at Mymensingh sadar upazila in Bangladesh
}

\author{
F. Islam ${ }^{\mathrm{a}}$, M. S. Hossain ${ }^{\mathrm{a}}$, S. C. Sarker ${ }^{\mathrm{a}}$, M. P. Choudhury ${ }^{\mathrm{b}}$ and A. \\ Majumder $^{\mathrm{a}}$
}

Bangladesh Agricultural University (BAU), Mymensingh

${ }^{b}$ Bangladesh Livestock Research Institute (BLRI), Savar, Dhaka, Bangladesh

\begin{abstract}
This study provided information on housing, feeds and feeding management, mating system and healthcare management of Black Bengal goats at rural villages of Mymensingh sadar upazila under Mymensingh district in Bangladesh. All farmers reared goats in semi-intensive system and most of them had goat house, provided bedding materials at winter season. Most of the farmers took bath of their goats at summer but a few of them did the same in winter season. Most of the farmers used concentrate feed with green grass and supplied water once in a day in particular waterer. Major sources of drinking water for goats were tube well and during rainy season most of the farmers grazed their goats. Farmers supplied little bit more grass and tree leaves to their lactating does than that of pregnant does while they supplied more amount of concentrates feed to their pregnant does than that of lactating does. Birth and weaning weight were higher in male kids than female kids. Few farmers vaccinated their goats. Farmers did not keep breeding buck and they did not use artificial insemination (AI) for their does. Spouses were the main contributor in goat keeping. Above discussions might be indicative that farmers were more careful about housing, feeding but less careful about health care and breeding buck keeping issues.
\end{abstract}

Key words: Black Bengal goat, feeds and feeding and breeding buck keeping

Please cite this article as: Islam, F., Hossain, M. S, Sarker, S. C. Choudhury, M. P. \& Majumder, A. (2016). Black Bengal goat keeping at Mymensingh Sadar upazila in Bangladesh. Journal of Bioscience and Agriculture Research, 06(02), 541-546.

This article is distributed under terms of a Creative Common Attribution 4.0 International License.

\section{Introduction}

Economy of Bangladesh is mainly driven by agricultural product and livestock is the most viable sector. Livestock is contributing about $2.73 \%$ of overall Gross Domestic Products (GDP) and 4.31\% export earnings from leather and leather goods of total export, $20 \%$ of the population is directly and $50 \%$ is partly dependent on this sector (Draft Sixth Five Year Plan, 2010). However, the total livestock population composed of 25.61 million goats, 23.44 million cattle, 14.54 million buffaloes and 3.17 million sheep (DLS, 2014). Goats are very important species of livestock, it has short generation intervals, higher rates of prolificacy and high market demand (Amin et al. 2001). Goat is performing a 
variety of functions, displays a unique ability to adapt and maintain themselves in harsh environments, dwarf-size animals produce a variety of products, mainly meat and skins, and contribute a major role in the national economy. Meat and skin obtained from the Black Bengal are of excellent quality and contributing in poverty alleviation particularly in subsistence level of farming for many small and landless farmer families at rural level (Amin, 2000). Poor people who have not ability to buy and rear large ruminants, goat is ideally suited for them. Goat husbandry is becoming an attractive activity mainly among the poor women (Choudhury et al. 2012). As goat is contributing a lot in the economy of rural villagers, mainly among the poor family, so to gather update information this study was under taken with the objectives to learn about present status of goat housing, to collect information about feeds and feeding of goats, to know about health care status and to update information about the mating system of Black Bengal goats in the rural villages of study area.

\section{Methodology}

The study was conducted at Beltoli and Sobagia villages under Sadar upazila of Mymensingh district. Data were collected from 16 goat owners at Beltoli village and 34 goat owners at Sobagia village under Sadar upazila of Mymensingh district using pre-structured questionnaire through door to visit. Data on housing of goats, feeds and feeding management, birth weight, weaning weight and mating system of Black Bengal goat were collected during June 2014 to July 2014. Descriptive statistics menu was used to measure mean values of body weight of goats and grass weight but analyses were performed for having the farmers' distribution under different studied parameters using the cross tabulation procedure under statistical package for the social sciences (SPSS, 1998) version 11.5.

\section{Results and Discussion}

\section{Housing of Black Bengal goats}

Farmers (Table 01) at study sites reared their goat in semi intensive system, though Hossain et al. (2015) reported few goat farmers reared their goats in free range and intensive system. Most of the farmers kept their goats at goat's house but Pattamarakha et al. (1997) found most of the farmers did not have shelters for their goats. However, maximum farmers (98\%) provided bedding material to their goats during winter season. Most of the farmers (84\%) took bath of their goat during summer while maximum farmers (82\%) did not take bath of their goats in winter season.

Table 01. Housing of Black Bengal goats

\begin{tabular}{|c|c|c|c|}
\hline Parameter & Category & Numberof farmers & $\%$ \\
\hline \multirow[t]{2}{*}{ Rearing system } & Confinement & 0 & 0 \\
\hline & Semi intensive & 50 & 100 \\
\hline \multirow[t]{4}{*}{ Night shelter } & Goat's house & 34 & 68 \\
\hline & Cattle's house & 4 & 8 \\
\hline & $\begin{array}{l}\text { Veranda of farmers living } \\
\text { room }\end{array}$ & 8 & 16 \\
\hline & Farmers living room & 4 & 8 \\
\hline \multirow{2}{*}{$\begin{array}{l}\text { Provide bedding } \\
\text { material during winter } \\
\text { season }\end{array}$} & Yes & 49 & 98 \\
\hline & No & 1 & 2 \\
\hline \multirow{2}{*}{$\begin{array}{l}\text { Bath during summer } \\
\text { season }\end{array}$} & Yes & 42 & 84 \\
\hline & No & 8 & 16 \\
\hline \multirow{2}{*}{$\begin{array}{l}\text { Bath during winter } \\
\text { season }\end{array}$} & Yes & 9 & 18 \\
\hline & No & 41 & 82 \\
\hline
\end{tabular}




\section{Feeds and Feeding of Black Bengal goats}

Most of the farmers (82\%) supplied concentrate feed with the green grass for their goats while very few farmers supplied green grass alone to their goats unlikely, Hossain et al. (2015) observed that few farmers (19.5\%) supplied concentrates with green grass to their goats. About $80 \%$ farmers used green grass during stall feeding, these farmers were using particular feeder for their goats but $82 \%$ farmers were using particular feeder for concentrates feeding. Most of the farmers (98\%) supplied water using particular waterer and $88 \%$ farmers supplied water to their goats but $86 \%$ farmers supplied water once in a day. Major sources of drinking water for goats were tube (84\%) well and $82 \%$ farmers supplied mild hot water in winter season. During rainy season $90 \%$ farmers grazed their goats and $76 \%$ farmers supplied tree leaves for their goats.

Table 02. Feeds and feeding management

\begin{tabular}{|c|c|c|c|}
\hline Parameter & Category & $\begin{array}{l}\text { Number of } \\
\text { farmers }\end{array}$ & $\%$ \\
\hline \multirow{2}{*}{ Feed ingredients } & Green grass & 9 & 18 \\
\hline & $\begin{array}{l}\text { Concentrates and green } \\
\text { grass }\end{array}$ & 41 & 82 \\
\hline \multirow{2}{*}{$\begin{array}{l}\text { Stall feeding with green } \\
\text { grass }\end{array}$} & Yes & 40 & 80 \\
\hline & No & 10 & 20 \\
\hline \multirow{2}{*}{$\begin{array}{l}\text { Particular feeder for green } \\
\text { grass feeding }\end{array}$} & Yes & 40 & 80 \\
\hline & No & 10 & 20 \\
\hline \multirow[t]{2}{*}{ Concentrate supply } & Yes & 41 & 82 \\
\hline & No & 9 & 18 \\
\hline \multirow{2}{*}{$\begin{array}{l}\text { Particular Concentrate } \\
\text { Feeder }\end{array}$} & Yes & 41 & 82 \\
\hline & No & 9 & 18 \\
\hline \multirow{2}{*}{$\begin{array}{l}\text { Particular waterer for } \\
\text { drinking water }\end{array}$} & Yes & 49 & 98 \\
\hline & No & 1 & 2 \\
\hline \multirow[t]{2}{*}{ Watering daily } & Yes & 44 & 88 \\
\hline & No & 6 & 12 \\
\hline \multirow[t]{2}{*}{ Watering } & Once in a day & 43 & 86 \\
\hline & Not counted & 7 & 14 \\
\hline \multirow{2}{*}{$\begin{array}{l}\text { Drinking water during } \\
\text { winter }\end{array}$} & Normal & 9 & 18 \\
\hline & Mild hot & 41 & 82 \\
\hline \multirow[t]{4}{*}{ Drinking water sources } & Tube well & 42 & 84 \\
\hline & Pond & 1 & 2 \\
\hline & Pond and lake & 2 & 4 \\
\hline & Tube well and pond & 5 & 10 \\
\hline \multirow[t]{2}{*}{ Feeding during rainy day } & Tree leaves (green) & 38 & 76 \\
\hline & $\begin{array}{l}\text { Green grass and tree } \\
\text { leaves }\end{array}$ & 12 & 24 \\
\hline \multirow[t]{2}{*}{ Graze in the rain time } & Yes & 45 & 90 \\
\hline & No & 5 & 10 \\
\hline
\end{tabular}

Farmers supplied little bit more grass and tree leaves to their lactating does than that of pregnant does while they supplied more amount of concentrates feed to their pregnant does than that of lactating does. The amount of grass, tree leaves and concentrate feed given to the pregnant doe were $2.39 \pm 0.09$ $\mathrm{kg} /$ day, $0.55 \pm 0.02 \mathrm{~kg} /$ day and $78.50 \pm 11.02 \mathrm{gm} /$ day, respectively (Table 03). However, farmers supplied $2.50 \pm 0.08 \mathrm{~kg}$ grass/day/doe, $0.64 \pm 0.03 \mathrm{~kg}$ tree leaves/day/doe and $60.00 \pm 5.89 \mathrm{gm}$ concentrate feed/day/doe during lactation. 
Table 03. Amount of different types of feeds at pregnant and lactating stage of goat

\begin{tabular}{|l|l|l|}
\hline Feed ingredients & Category of goat & $\begin{array}{l}\text { Allocated amount per } \\
\text { day }\end{array}$ \\
\hline \multirow{2}{*}{ Grass $(\mathrm{kg})$} & Pregnant doe & $2.39 \pm 0.09$ \\
\cline { 2 - 3 } & Lactating doe & $2.50 \pm 0.08$ \\
\hline \multirow{2}{*}{ Tree leaves $(\mathrm{kg})$} & Pregnant doe & $0.55 \pm 0.02$ \\
\cline { 2 - 3 } & Lactating doe & $0.64 \pm 0.03$ \\
\hline Concentrate $(\mathrm{gm})$ & Pregnant doe & $78.50 \pm 11.02$ \\
\cline { 2 - 3 } & Lactating doe & $60.00 \pm 5.89$ \\
\hline
\end{tabular}

\section{Birth and weaning weights of Black Bengal goats}

Birth weight of female and male kids in the surveyed areas were found $1.35 \pm 0.06 \mathrm{~kg}$ and $1.65 \pm 0.10 \mathrm{~kg}$, respectively (Table 04). Weaning weight of female and male kids were found $5.02 \pm 0.12 \mathrm{~kg}$ and $5.49 \pm 0.14 \mathrm{~kg}$, respectively. Birth and weaning weight of male kids were higher than that of female kids and birth weight at present study were higher than $1.28 \pm 0.11 \mathrm{~kg}$ (Faruque et al. 2010). However, present study reported that body weight at first heat was $7.44 \pm 0.10 \mathrm{~kg}$ which was much lowere than that of live weight reported by Chowdhury et. al. (2002) for the doe at her first kidding period.

\section{Table 04. Body weights of goat at different stage of goat}

\begin{tabular}{|l|l|}
\hline Parameter & Means \pm SE \\
\hline Female kids birth weight $(\mathrm{kg})$ & $1.35 \pm 0.06$ \\
\hline Male kids birth weight $(\mathrm{kg})$ & $1.65 \pm 0.10$ \\
\hline Female kids weaning weight $(\mathrm{kg})$ & $5.02 \pm 0.12$ \\
\hline Male kids weaning weight $(\mathrm{kg})$ & $5.49 \pm 0.14$ \\
\hline Body weight at first heat $(\mathrm{kg})$ & $7.44 \pm 0.10$ \\
\hline
\end{tabular}

\section{Vaccination and de-worming}

A few numbers of farmers (8\%) vaccinated their goats though $50 \%$ farmers de-wormed their goats in the study area (Figure 01) and this result contradict with Hossain et al. (2015) who found most of the farmers vaccinated their goats.

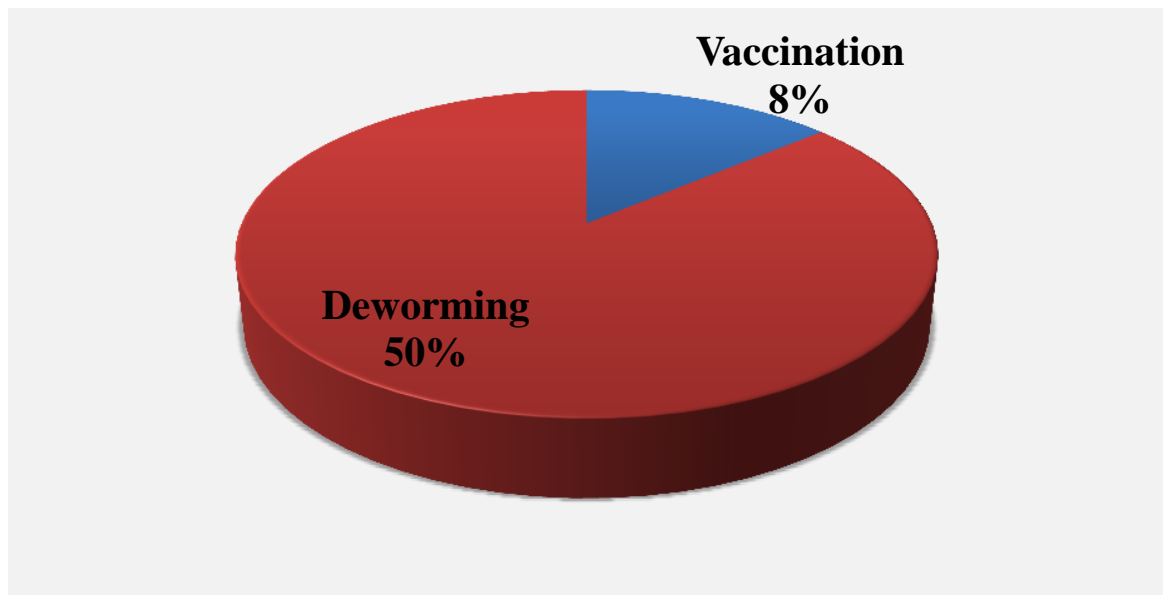

Figure 01. Vaccination and de-worming practiced by the goat farmers 


\section{Mating system of Black Bengal goats}

Farmers (100\%) did not keep breeding buck and most of the farmers (92\%) used villagers buck while all breeding buck keeping villagers took service fee and the present study were in line with Hossain et al. (2015). However, artificial insemination was not practiced by the farmers (Table 05) and a few farmers (8\%) used Bangladesh Agricultural University (BAU) bucks.

Table 05. Mating system of Black Bengal goats

\begin{tabular}{|l|l|l|l|}
\hline Parameter & Category & Number of farmers & $\%$ \\
\hline \multirow{2}{*}{ Buck kept by the farmers } & Yes & 0 & 0 \\
\cline { 2 - 4 } & No & 50 & 100 \\
\hline \multirow{2}{*}{ natural Insemination } & Villagers bucks & 46 & 92 \\
\cline { 2 - 4 } & BAU bucks & 4 & 8 \\
\hline \multirow{2}{*}{ Natural Insemination fee } & $\begin{array}{l}\text { Insemination fee } \\
\text { received }\end{array}$ & 50 & 100 \\
\cline { 2 - 4 } & No service fee taken & 0 & 0 \\
\hline $\begin{array}{l}\text { Artificial insemination (AI) } \\
\text { Practice }\end{array}$ & Yes & 0 & 0 \\
\cline { 2 - 4 } & No & 50 & 100 \\
\hline
\end{tabular}

\section{Ownership and contribution of family members}

All spouses were the main contributor in goat keeping though, most of the household heads contributed in goat keeping but few household head had the ownership of goats and this study were in line with Hossain et al. (2015). All farmers kept goats for selling and $98 \%$ farmers preferred both sex kids in the studied areas (Table 06).

Table 06. Ownership and family members contribution

\begin{tabular}{|c|c|c|c|}
\hline Parameter & Category & $\begin{array}{l}\text { Number of } \\
\text { farmers }\end{array}$ & $\%$ \\
\hline \multirow{2}{*}{$\begin{array}{l}\text { Contribution of household head in } \\
\text { goat keeping }\end{array}$} & Yes & 48 & 96 \\
\hline & No & 2 & 4 \\
\hline \multirow[t]{3}{*}{ Main contribution in goat keeping } & Wife & 50 & 100 \\
\hline & Husband & 0 & 0 \\
\hline & Children & 0 & 0 \\
\hline \multirow{2}{*}{$\begin{array}{l}\text { Male member of household take } \\
\text { part in goat keeping }\end{array}$} & Yes & 23 & 46 \\
\hline & No & 27 & 54 \\
\hline \multirow[t]{2}{*}{ Goat ownership } & House hold head & 9 & 18 \\
\hline & Other family members & 41 & 82 \\
\hline \multirow[t]{3}{*}{ Goat keeping purpose } & $\begin{array}{l}\text { Income generation } \\
\text { through sale }\end{array}$ & 50 & 100 \\
\hline & Sacrifice & 0 & 0 \\
\hline & Consumption & 0 & 0 \\
\hline \multirow[t]{3}{*}{ Kids preference } & Male & 1 & 2 \\
\hline & Female & 0 & 0 \\
\hline & Both & 49 & 98 \\
\hline
\end{tabular}

\section{Conclusion}

All farmers reared goats in semi-intensive system and most of them had goat house, provided bedding materials at winter season. Most of the farmers took bath of their goats at summer but a few of them 
did the same in winter season. Most of the farmers used concentrate feed with green grass and supplied water once in a day in particular waterer. Major sources of drinking water for goats were tube well and during rainy season most of the farmers grazed their goats. Farmers supplied little bit more grass and tree leaves to their lactating does than that of pregnant does while they supplied more amount of concentrates feed to their pregnant does than that of lactating does. Birth and weaning weight were higher in male kids than female kids. Few farmers vaccinated their goats. Farmers did not keep breeding buck and they did not use AI for their does. Spouses were the main contributor in goat keeping. Most of the household heads contributed in goat keeping but few household head had the ownership of goats. Above discussions might be indicative that farmers were more careful about housing, feeding but less careful about health care and breeding buck keeping issues.

\section{Acknowledgement}

Authors are thankful to the Black Bengal goat farmers of Mymensingh Sadar upazila under Mymensingh district in Bangladesh for their spontaneous support in collecting information for this study during questionnaire sessions. This study was designed and conducted through self-financing of the authors.

\section{Reference}

1. Amin, M. R. (2000). Genetic Improvement of production traits in selective breeding and cross breeding. A Ph.D. Thesis. Dept of Anim. Breeding and Genetics, Bangladesh Agricultural University, Mymensingh.

2. Amin, M. R. Husain, S. S. \& Islam, A. B. M. M. (2001). Reproductive pecularities and litter weight in different genetic groups of Black Bengal Does. Asian-Aust. J. Anim. Sci., 14(3), 297-301.

3. Choudhury, M. P., Sarker, S. C. , Islam, F., Ali, A., Bhuiyan, A. K. F. H., Ibrahim, M. N. \& Okeyo, A.. M. (2012). Morphometry and performance of Black Bengal goats at the rural community level in Bangladesh. Bang. J. Anim. Sci., 41 (2), 83-89.

4. Chowdhury, S. A., Bhuiyan, M.S. A. \& Faruque, S. (2002). Rearing Black Bengal goat under semiintensive management, Physiological and reproductive performances. Asian-Aus.J. Amin. Sci., 15(4), 477-484. http://dx.doi.org/10.5713/ajas.2002.477

5. DLS, (2014). Department of livestock services. Livestock statistics. Memeogram. Dhaka, Bangladesh.

6. Draft, S. F. Y. P. (2010). The draft sixth five year plan (2011-2015). Planning commission, government of Bangladesh. Paper presented at the Workshop held on $6^{\text {th }}$ January, 2010 in DLS conference room, Dhaka.

7. Faruque, S., Chowduury S. A., Siddiquee, N. U. \& Afroz, M. A. (2010). Performance and genetic prarameters of economically important traits of Black Bengal goat. J. Bang. Agril. Univ., 8 (1), 67-78.

8. Hossain, M. S., Akhtar, A., Hossain, M. H., Choudhury, M. P. \& Islam, F. (2015). Goat husbandry practices in southern region of Bangladesh. J. Biosci. Agric. Res., 05 (02), 59-64.

http://dx.doi.org/10.18801/jbar.050215.55

9. Pattamarakha, K., Tanapanyarachwong, J. \& Saithanoo, S. (1997). The use of recommended goat husbandry practices by farmers in southern thailand. Asian-Aust. J. Anim. Sci., 10 (6), 587592.

http://dx.doi.org/10.5713/ajas.1997.587

10. SPSS, (1998) Windows for version-11.5. (Microsoft Corp. 1998). Trends SPSS Inc., Michigan Avenue, Chicago, IL. 19-182. 